\title{
Moralitas, Bisnis dan Penegakan Hukum di Indonesia
}

\author{
Liliana Tedjosaputro
}

\begin{abstract}
This article discusses the vivid correlation between morality and law enforcement of the business doers. The morality constitutes an important component in managing business. It is considered very important in relations to the business target, and this is consecuted by applying it appropriately on the basis of the situation and existing legal norms.
\end{abstract}

\section{Pendahuluan}

Krisis moneter dan krisis kepercayaan yang melanda Indonesia telah membawa kesulitan-kesulitan bagi kalangan pelaku usaha. Pada satu sisi pelaku usaha dianggap sebagai penyebab buruk atas ambruknya perekonomian Indonesia, di samping pola kepemimpinan orde baru yang bersifat otoriter dan diskriminatif. Pada sisi yang lain pelaku usaha menghadapi orientasi global yang menuntut kualitas barang untuk dapat bersaing dengan negara-negara lain, serta perubahan ekonomi yang tidak menentu yang masih berlangsung hingga saat ini.

Kondisi demikian telah menimbulkan beberapa masalah, antara lain, meningkatnya kepekaan yang secara formal tertuang dalam bentuk peraturan perundang-undangan di negara-negara tertentu yang bertujuan untuk membatasi produk-produk dari negaranegara tertentu.
Di samping itu, perkembangan informasi yang demikian pesatnya membawa pula dampak negatif bagi para pengusaha, karena "isu-isu" negatif yang selalu membebani dunia usaha Indonesia.

Kasus Bank Bali likuidasi bank-bank, kasus ruilslag dan masih banyak kasus lain yang melibatkan banyak para pengusaha kelas atas Indonesia, dianggap sebagai salah satu faktor penting rendahnya moralitas pengusaha Indonesia. Hal itu mengakibatkan hilangnya kepercayaan dari negara lain. Oleh karena itu wajar saja apabila pengusaha luar negeri pernah mempercayai Letter of Credit yang dikeluarkan oleh bank-bank Indonesia untuk melakukan transaksi dengan pengusaha Indonesia.

Dari aspek moralitas, ketidakpercayaan ini merupakan wujud tidak adanya pengakuan terhadap keseluruhan norma-norma, nilai-nilai 
dan sikap yang dianut, diyakini dan dijalankan oleh suatu masyarakat. Di dalam moralitas terdapat unsur-unsur keyakinan dan sikap batin yang bukan hanya sekedar penyesuaian diri dengan aturan dari luar.

Pelaku bisnis sebagai bagian dari masyarakat tidak dapat memisahkan diri dari norma-norma dan nilai-nilai yang berlaku di masyarakatnya. Selain harus pula mengikuti norma-norma dan nilai-nilai yang berlaku di kalangan bisnis. Ketidakpercayaan dan ketidakberdayaan yang diterima sebagian pelaku bisnis akan mempengaruhi pula ketidakpercayaan pada bangsa Indonesia secara keseluruhan.

Dari aspek tanggung jawab, ketidakpercayaan dan ketidakberdayaan ini merupakan beban moral bagi para pelaku bisnis, karena dibebankan pada kehendak manusia yang bebas untuk melaksanakan kewajiban. Tanggung jawab merupakan perwujudan dari nilai-nilai moral dalam berperilaku pada diri manusia. Hilangnya kepercayaan dan keberdayaan berarti hilang pula nilai-nilai hakiki manusia yang merdeka.

Dalam tulisan ini, penekanan pada tiga bagian sebagai bagian tak terpisahkan merupakan satu upaya untuk lebih mempertegas pemahamannya. Bisnis yang bersifat universál, tetap harus dilandasi moralitas yang tinggi. Namun demikian, pengabaian nilai-nilai moral tidak ada sanksinya yang tegas, sehingga diperlukan perangkat peraturan perundang-undangan yang mempunyai sanksi yang tegas dan jelas dalam upaya melindungi hak dan kewajiban yang ada dalam melaksanakan bisnis.

\section{Max Sceler dan Teori Kesalahan}

Dalam kehidupan manusia dikenal berbagai jenis kesalahan. Kesalahan yang berpasangan dengan kebaikan merupakan unsur kodrati manusia. Kesalahan pada umumnya diartikan sebagai pelanggaran. Akan tetapi; tidak setiap kesalahan dapat dikategorikan sebagai kesalahan moral, misalnya seseorang yang melanggar ketertiban lalu lintas, belum tentu merupakan kesalahan moral, karena SIM-nya ketinggalan atau belum memahami rambu-rambu lalu lintas, ataupun seseorang yang salah dalam membaca dalam bahasa Inggris bukanlah suatu kesalahan moral.

Dengan demikian kesalahan dapat diartikan sebagai pelanggaran apabila orang yang berbuat salah itu mengerti dan memahami serta berbuat dengan sengaja.

Dalam memahami kedalaman kesalahan (moral) ini, seorang filosuf Jerman bernama Max Sceler, dalam karyanya yang berjudul Vom Ewigen im Menschen atau tentang yang abadi dalam manusia, Sceler menulis tentang: "Reue und Widergeburf", yang artinya menyesal dan lahir lagi. Dalam tulisan ini Sceler mengkristalisasikan pikiran-pikiran tentang manusia dan dosa atau kesalahan moral. Reue atau penyesalan adalah gerak kodrati yang berasal dari dalam diri manusia sendiri. Gerak itu adalah rasa, akan tetapi rasa yang amat dalam, rasa yang sangat fundamental, yang muncul dari dasar jiwa. Rasa seperti itu dialami manusia atau melihat diri sendiri sebagai tak bernilai sebagai kekosongan. Mengalami rasa tak bernilai, rasa kekosongan itulah yang disebut merasa bersalah, merasa berdosa. 
Satu-satunya yang dapat menerangkan adanya kesadaran akan kesalahan moral adalah pengakuan, bahwa manusia itu dalam perbuatannya menangkap diri sendiri sebagaimana mestinya, dalam hubungannya dengan realitas yang sebenarnya, terutama dengan Tuhan yang menciptakan. ${ }^{1}$ Dalam kaitannya dengan pelaku bisnis, rasa ini seharusnya ada, sehingga konsep atau pemikiran-pemikiran dalam mencapai tujuannya dengan menghalalkan segala cara dapat lebih dieliminir. Rasa bersalah harus muncul dalam melakukan bisnis, sehingga akan muncul persaingan sehat, fair dan kompetitif tetap pada jalur yang sebenamya.

\section{Bisnis sebagai Suatu Profesi}

Bisnis merupakan salah satu aktivitas usaha yang utama dalam menunjang perkembangan ekonomi. Menurut Ricard Burton Simatupang, bahwa bisnis diartikan sebagai keseluruhan kegiatan usaha yang dijalankan oleh orang atau badan secara teratur dan terus menerus, yaitu berupa kegiatan mengadakan barang-barang atau jasa-jasa ataupun fasilitas-fasilitas untuk diperjualbelikan, dipertukarkan atau disewagunakan dengan tujuan mendapatkan keuntungan.Kemudian menurut Black's Law Dictionary" "Business: employment, occupation, profession, or comercial activity engaged in for gain or livelihood. Activity or enterprise for gain, benefit, advantage or livelihood..."
Dalam hal ini bisnis menyangkut berbagai macam aspek, karena tidak hanya menyangkut para pelaku bisnis itu sendiri, tetapi juga komponen-komponen yang terlibat di dalamnya, seperti pekerja, kepemilikan, kreditur, debitur dan bisnis dipandang sebagai profesi.

Dalam hal ini bisnis dapat pula diasumsikan dalam tiga hal, yaitu:

1. Bisnis diasumsikan sebagai usaha dagang atau usaha komersial dalam dunia perdagangan yang berhasil dan tahan lama;

2. Bisnis diasumsikan sebagai bisnis modern yang diwarnai persaingan yang berlangsung secara ketat dan fair. Secara konkrit diasumsikan berlangsung dalam pasar yang terbuka, bebas dan tidak tertutup ataupun monopolistis. Ini berarti bebas dari kepentingan politik atau kepentingan-kepentingan tertentu lainnya;

3. Keuntungan bukan tujuan satu-satunya. Ini berarti harus dilandasi nilai-nilai dalam melakukan usaha.

Dalam melakukan bisnis, terdapat nilainilai etis yang harus diperhatikan sebagai perwujudan etika yang terkandung dalam suatu profesi. Nilai-nilai etis ini akan menyadarkan adanya hak dan kepentingan orang lain yang tidak boleh dilanggar dalam praktik bisnis. Demikian pula adanya legal politic dalam praktik bisnis, sehingga harus mematuhi hukum dan aturan serta peran pemerintah dalam melaksanakan bisnis yang baik.

1Drijarkara N. 1981. Percikan Filsafat. Jakarta: Pembangunan.HIm. 28-36.

${ }^{2 H e n r y ~ C a m p b e l l ~ B l a c k . ~ 1990 . ~ B l a c k ' s ~ L a w ~ D i c t i o n a r y . ~ S i x t h ~ E d i s t i o n . ~ S T . ~ P a u l ~ M i n n: ~ W e s t ~ P u b l i s h i n g . ~}$ Co. Him. 198. 
Bisnis juga merupakan suatu profesi, sehingga menuntut keahlian-keahlian khusus untuk dapat berjalan dan berkembang. Pengertian profesi itu sendiri dan ruang lingkupnya sangat beragam.

Dalam kamus populer oleh Habeyb, profesi diartikan sebagai pekerjaan dengan keahlian khusus sebagai mata pencaharian tetap. Kemudian menurut ensiklopedi manajemen dijelaskan profession, profesi ialah suatu jenis pekerjaan yang karena sifatnya menuntut pengetahuan yang tinggi, khusus dan latihan yang istimewa. Dengan demikian suatu profesi itu mempunyai unsurunsur sebagai berikut:

\section{a. suatu pekerjaan yang memerlukan keahlian; \\ b. untuk itu perlu mendapatkan latihan khusus; \\ c. memperoleh penghasilan daripadanya.}

Dalam praktiknya, setiap profesi tidak hanya mempunyai dimensi teknis dan ketrampilan, tetapi juga moral dan filsafat. ${ }^{3}$ Hal ini berarti dalam melakukan bisnis harus dilandasi pula oleh etika yang diwujudkan dengan adanya unsur tanggung jawab sosial dan tidak didasarkan pada keuntungan semata.

\section{Penegakan Hukum dan Etika Bisnis}

Penegakan hukum dalam masyarakat modem tidak saja diartikan dalam arti sempit tetapi juga dalam arti luas, seperti di Indone- sia penegakan hukum dikaitkan dengan unsur manusia dan lingkungan sosialnya. Manusia harus menyesuaikan diri dengan lingkungan sosialnya, dan sebaliknya lingkungan sosial tersebut diisi dan dipengaruhi pula oleh perilaku-perilaku manusianya.

Perilaku manusia dalam masyarakat tidaklah bersifat bebas, melainkan didisiplinkan oleh jaringan kaidah-kaidah yang terdapat di dalam masyarakat. Kaidah-kaidah ini merupakan suatu rambu-rambu yang mengikat dan membatasi perilaku orang di dalam masyarakat, termasuk di dalamnya para pejabat penegak hukum. Dalam arti yang lebih luas atau hukum pada umumnya adalah keseluruhan kumpulan peraturan-peraturan atau kaidah-kaidah dalam suatu kehidupan bersama. Keseluruhan peraturan tentang perilaku yang berlaku dalam suatu kehidupan bersama yang dapat dipaksakan pelaksanaannya dengan suatu sanksi.

Disisi lain, Soedarto menegaskan ${ }^{4}$ bahwa penegakan hukum dapat bersifat preventif, represif dan kuratif dan juga dapat diterapkan pada bidang hukum pidana, hukum perdata dan hukum administrasi. Kesemua sistem penegakan hukum tersebut masing-masing didukung dan dilaksanakan oleh alat perlengkapan negara atau aparatur penegak hukum yang mempunyai aturannya masingmasing pula.

Penegakan hukum yang bersifat preventif adalah usaha pencegahan kejahatan, upaya untuk menjaga agar orang yang bersangkutan serta masyarakat pada umumnya tidak

3Satjipto Rahardjo. 1983. Masalah Penegakan Hukum Suatu Tinjauan Sosiologis. Bandung: Sinar Harapan. HIm. 1.

‘Soedarto. 1986. Kapita Selekta Hukum Pidana. Bandung:Alumni. HIm. 111. 
melakukan kejahatan. Penegakan hukum represif adalah segala tindakan yang dilakukan oleh aparatur penegak hukum sesudah terjadi kejahatan. Kemudian penegakan hukum kuratif adalah penegakan hukum preventif dalam arti seluas-luasnya dalam usaha penanggulangan kejahatan yang lebih dititikberatkan pada tindakan terhadap orang yang melakukan kejahatan. ${ }^{5}$

Penegakan hukum tidak hanya mencakup law enforcement tetapi juga peace maintenance, karena penegakan hukum merupakan suatu proses penyerasian antara nilai-nilai, kaidah-kaidah, dan pola perilaku nyata, yang bertujuan untuk mencapai kedamaian. Tugas utama penegakan hukum adalah mencapai keadilan. Melalui penegakan hukum inilah hukum menjadi kenyataan.

Dalam bidang hukum, keadilan merupakan tugas bagi hukum atau merupakan suatu kegunaan hukum. Keadilan yang menjadi tugas hukum merupakan hasil penyerasian atau keserasian antara kepastian hukum dan kesebandingan hukum.

Secara ideal kepastian hukum merupakan pencerminan dari asas neminem laedere, sedangkan kesebandingan hukum merupakan pencerminan dari asas suum cuiqe tribuere.

Asas neminem laedere yakni jangan merugikan orang lain. Secara luas asas ini berarti apa yang anda tidak ingin alami, janganlah menyebabkan orang lain mengalaminya. Asas suum tribuere yakni bertindaklah sebanding. Secara luas asas ini berarti apa yang boleh anda mendapat, biarkanlah orang lain berikhtiar mendapatkannya.

Kedua asas tersebut di atas, masingmasing merupakan satu kutub dalam citra keadilan. Asas neminem laedere merupakan sendi equality yang ditujukan terhadap umum tanpa kecuali, dengan lain perkataan, sendi ini merupakan asas bagi pergaulan hidup. Asas suum cuiqe tribuere merupakan sendi equity yang diarahkan pada penyamaan apa yang tidak berbeda dan membedakan apa yang tidak sama. Dalam pergaulan hidup sendiri equity akan dialami pada hal-hal yang khusus dan konkrit.

Oleh karena asas-asas tepa-salira yakni neminem laedere dan suum cuiqe tribuere merupakan kutub-kutub citra keadilan, maka keadilan sebagai keadaan merupakan keserasian antara kedua asas tersebut. Sebagai proses, maka keadilan merupakan penyerasian kedua asas tersebut di atas. ${ }^{6}$ Apa yang menjadi haknya orang lain harus diberikan dan dilindungi sebanding dengan apa yang telah dilakukannyal diberikannya.

Bagi pelaku bisnis, asas neminem laedere dan asas suum cuiqe tribuere sangat perlu untuk dihayati dan dikembangkan. Asas kesebandingan dan jangan merugikan orang lain bagi pihak-pihak yang terlibat dalam dunia perdagangan berarti mengakui adanya hak dan kewajiban bagi masing-masing pihak. Pihak-pihak tersebut tidak hanya para pelaku bisnis, tetapi juga, konsumen, masyarakat luas, karyawan, kreditor dan Pemerintah.

5/bid. HIm. 121.

"Soerjono Soekanto. 1988. "Peningkatan Wibawa Penegakan Hukum (Suatu Tinjauan Sosio Yuridis)". Varia Peradilan Tahun III No. 28. Him. 148. 
Paling tidak ada tiga sasaran dan lingkup etika bisnis, yaitu:

1. Etika bisnis sebagai suatu profesi membahas berbagai prinsip, kondisi, dan masalah yang terkait dengan praktik bisnis yang baik dan etis. Ini berarti suatu himbauan dan harapan agar pelaku usaha dalam menjalankan bisnisnya sesuai dengan nilai-nilai etis dan dilakukan dengan baik.

2. menyadarkan konsumen, buruh atau karyawan dan masyarakat luas, akan hak dan kepentingan mereka yang tidak boleh dilanggar dalam praktik bisnis. Hal ini seringkali dilupakan dan jarang disinggung dalam berbisnis. Pada hal sasaran ini sangat vital dalam kompetisi bisnis modern.

3. Etika bisnis juga berbicara mengenai sistem ekonomi yang sangat menentukan etis tidaknya suatu praktik bisnis. Ini menekan pentingnya legal-politis bagi - praktik bisnis yang baik, yaitu pentingya hukum dan aturan serta peran pemerintah yang efektif menjamin berlakunya aturan bisnis yang sehat dan konsekuen.

Secara lebih jelas, bagi pelaku bisnis terdapat prinsip-prinsip yang seharusnya dipatuhi sebagai etika, yaitu:

1. prinsip otonomi;

2. prinsip kejujuran;

3. prinsip keadilan;

4. prinsip saling menguntungkan (mutual benefit principle);

\section{5. prinsip integritas moral ${ }^{7}$}

\section{ad.1. Prinsip Otonomi}

Otonomi adalah sikap dan kemampuan manusia untuk mengambil keputusan dan bertindak berdasarkan kesadarannya sendiri tentang apa yang dianggapnya baik untuk dilakukan. Orang bisnis adalah orang yang otonom, artinya dia sadar sepenuhnya pada bidang kegiatannya, situasi yang dihadapi, tuntutan yang ada padanya, tuntutan dan aturan yang berlaku padanya. Pada orang bisnis, visi dan misinya harus jelas. Oleh karena itu sikap otonom ini harus dipegang agar dalam melakukan sesuatu, dia sadar bahwa yang dilakukan itu baik dan tidak sekedar mengikuti nilai-nilai moral yang ada.

Nilai kesadaran dalam mengambil keputusan ini harus pula diikuti oleh tanggung jawab yang besar.

Dengan demikian orang yang otonom adalah orang yang tahu tindakannya, bebas dalam bersikap dan mengambil keputusan, tetapi sekaligus juga bertanggung jawab atas tindakan dan keputusannya tersebut, atau mengetahui akibatnya yang mungkin timbul dan terjadi.

\section{ad. 2. Prinsip Kejujuran}

Secara sepintas, prinsip ini terdapat unsur yang kontradiktif, karena, bisnis dipandang pada profit oriented, sementara kejujuran mengandung ajaran moralitas. Kejujuran dapat menjadi kunci keberhasilan, apabila ingin bisnisnya itu bertahan dan berkembang. Kejujuran yang dilandasi iktikad baik harus

${ }^{7}$ A. Sonny Keraf. 1998. Etika Bisnis dan Relevansinya. Yogyakarta: Kanisius. Hlm. 74-79. 
dapat dijadikan salah satu pilar utama dalam mengembangkan dunia usaha.

Prinsip kejujuran ini menjadi penting dengan melihat pada:

a. Pemenuhan syarat-syarat perjanjian.

Dalam memenuhi syarat-syarat perjanjian ini, kejujuran sangat penting artinya bagi para pihak, karena sangat menentukan relasi dan kelangsungan bisnisnya. Dalam егa global, informasi-informasi dan komunikasi yang demikian cepat dan canggih sangat memungkinkan terbukanya pihak yang berbuat curang dalam melakukan bisnisnya.

b. Penawaran barang dan jasa

Penawaran barang dan jasa harus sebanding dengan mutu dan harganya. Kepercayaan konsumen adalah kunci pokok. Penipuan oleh pelaku bisnis, entah melalui iklan, pelayanan dan cara-cara lain yang tidak fair akan menyebabkan produknya ditinggalkan oleh konsumen.

c. Hubungan kerja intern dalam perusahaan

Kejujuran yang tercipta dalam lingkungan perusahaan merupakan inti dari kekuatan perusahaan itu. Sulit dipercaya suatu perusahaan akan bertahan dan berkembang, kalau hubungan kerja dalam perusahaan itu tidak dilandasi kejujuran, baik oleh karyawankaryawannya maupun oleh pimpinannya.

\section{ad. 3. Prinsip Keadilan}

Prinsip ini menuntut agar setiap orang diperlakukan secara sama sesuai dengan aturan yang adil dan sesuai dengan kriteria rasional yang objektif dan dapat dipertanggungjawabkan. Ini berarti tidak boleh ada yang dirugikan hak dan kepentingannya.
Keadilan di sini merupakan keadilan yang bersifat distributif, yaitu. orang harus memperoleh apa yang menjadi haknya dan dilindungi kepentingannya sesuai dengan apa yang diberikan olehnya.

\section{ad. 4. Prinsip Saling Menguntungkan (Mutual Benefit Principle)}

Prinsip ini untuk mengakomodir hakekat dan tujuan bisnis. Kalau pada prinsip keadilan, tidak boleh ada yang dirugikan, maka pada prinsip ini harus saling menguntungkan. $\mathrm{Hal}$ ini berarti harus ada win-win solution.

\section{ad. 5. Prinsip Integritas Moral}

Prinsip ini penting dalam menjalankan bisnis agar tetap terjaga namanya maupun perusahaannya. Prinsip ini berlaku dan harus diberlakukan keluar dan ke dalam perusahaan.

Prinsip-prinsip dalam etika bisnis ini pada dasarnya tidak berbeda dengan prinsip-prinsip hukum. Dari prinsip-prinsip etika bisnis tersebut telah tercakup dalam asas neminem laedere dan asas suum cuiqe tribuere. Meskipun sanksi-sanksinya hanya sanksi moral, namun apabila dilanggar dapat pula sanksi hukum terdapat di dalamnya, misalnya; pada prinsip kejujuran, dengan mengabaikan syarat-syarat perjanjian yang disepakati dapat dituntut berdasarkan wanprestasi.

\section{Peran Stakeholders dalam Praktik Bisnis}

Dalam menjalankan (praktik) bisnis, terdapat pihak-pihak yang berperan (stakeholders), baik sebagai pihak yang secara langsung terlibat dalam perdagangan maupun pihak lain yang tidak langsung berperan tetapi mempunyai posisi yang strategis. Para pihak 
tersebut mempunyai tanggungjawab sesuai dengan perannya masing-masing.

Stakeholders dapat dibagi dalam dua kelompok yaitu: kelompok primer, yaitu pemilik modal atau saham, kreditur, karyawan. Pemasok, konsumen, penyalur, pesaing serta rekanan dan kelompok sekunder yaitu pemerintah (setempat atau asing), kelompok sosial (seperti LSM), media massa dan masyarakat luas.

Kelompok primer berperan terhadap hidup matinya perusahaan, sehingga tidak boleh merugikan satupun di antara stakeholders tersebut.

Kelompok sekunder juga harus diperhatikan dan diperhitungkan, karena dapat pula mempengaruhi hidup matinya suatu perusahaan. Misal: Pengawasan LSM terhadap pencemaran limbah oleh suatu perusahaan, sangat merepotkan suatu perusahaan. Demikian juga pemberitaan di media massa sangat mempengaruhi produkproduk yang berlaku di pasaran.

Dalam bisnis modern peran kelompok sekunder sangat aktif. Kelompok sekunder seperti: LSM dapat melakukan penelitian, survey, pengamatan maupun menerima laporanlaporan dari masyarakat, juga di dukung oleh transparansi pelaporan melalui media massa.

Dengan demikian pendekatan stakeholders.ini periu dikembangkan, karena berpengaruh padakeputusan dan tindakan bisnis. Prinsipnya tidak merugikan kepentingan pihak-pihak yang terlibat dalam kegiatan bisnis.

\section{Simpulan}

Ada korelasi yang jelas antara moralitas dan penegakan hukum bagi para pelaku bisnis. Moralitas merupakan komponen penting dalam melakukan usaha/ bisnis. Pentingnya moralitas ini berkaitan dengan tujuan bisnis dengan mengintroduksikan secara sesuai dengan situasi dan kondisi serta norma-norma hukum yang berlaku.

Konkritisasi hukum bagi para pelaku bisnis terjadi apabila terdapat pelanggaranpelanggaran terhadap peraturan-peraturan yang berlaku. Meskipun demikian penyelesaiannya tidak dapat dilakukan hanya dengan hukum saja, tetapi juga menyangkut aspek-aspek yang lain, seperti politik, ekonomi, sosial dan kebudayaan suatu masyarakat.

\section{Daftar Pustaka}

Black, Henry Campbell. 1990. Black's Law Dictionary. sixth edition. S.T. Paul. Minn: West Publishing Co.

Liliana, Tedjosaputro. 1995. Etika Profesi Notaris Dalam Penegakan Hukum Pidana. Yogyakarta: Bigraf Publishing.

N. Drijarkara. 1988. Percikan Filsafat. Jakarta: Pembangunan.

Richard Burton Simatupang. 1996. Aspek Hukum dalam Bisnis. Jakarta: Rineka Cipta.

Satjipto Rahardjo. 1983. Masalah Penegakan Hukum Suatu Tinjauan Sosiologis. Bandung: Sinar Baru.

Soerjono Soekanto. 1988. "Peningkatan Wibawa Penegakan Hukum (Suatu Tinjauan Sosio Yuridis)".Varia Peradilan Tahun III No. 28.

Soedarto. 1986. Kapita Selekta Hukum

Pidana. Bandung: Alumni. 
Sondang P.Siagian.1996. Etika Bisnis. Sonny Keraf, A..1998. Etika Bisnis Tuntutan Jakarta: Pustaka Binaman Pressindo.

dan Relevansinya. Yogyakarta: Kanisius.

$* *$ 